\title{
Histology and Surface Ultra-Structure of the Gill of A Minor Carp, Labeo bata (Hamilton)
}

\author{
I. Samajdar, D. K. Mandal* \\ Department of Zoology, Visva-Bharati, Santiniketan-731235 West Bengal India \\ Received 8 August 2016, accepted in final revised form 1 March 2017
}

\begin{abstract}
The histology and surface ultra-structures of the gill epithelium of Labeo bata has been examined through light and electron microscopy. Gill arches bear double rows of primary lamellae and each primary lamella is provided with two rows of delicate rectangular secondary lamellae on its upper and lower surfaces. Gill arches and filaments are lined by thick stratified epithelium while the epithelium of secondary lamella is made up of thin single layered pavement cells. The thin epithelium is supported and kept apart from each other by the pillar cells. The pavement cells are polygonal with well-defined cell boundary and microridges on its apical surface. The epithelial cells are interspersed by large chloride cells located at the base of secondary lamellae and PAS positive mucous cells. Mucous cells are found abundant at the base and tip of the primary lamellae. Taste buds are found on the concave anterior faces of gill arches. The short and soft gill rakers are covered with stratified epithelium. This finding demonstrated that the fish has well developed respiratory system matching to its active life.
\end{abstract}

Keywords: Gill morphology; Histology; SEM; Carp; Labeo bata.

(C) 2017 JSR Publications. ISSN: 2070-0237 (Print); 2070-0245 (Online). All rights reserved. doi: http://dx.doi.org/10.3329/jsr.v9i2.29195 J. Sci. Res. 9 (2), 201-208(2017)

\section{Introduction}

Labeo bata is a commercial food fish in India and study on the morpho-anatomy of its different organs draw attention among the scientists [1,2]. Fish gill is the main respiratory organ of fish as well as responsible for excretion of nitrogenous wastes, acid-base balance and ionic regulation [3,4] and food acquisition. Extensive studies have been conducted and literature available on the gill structure and respiratory physiology of fish [5-7]. Each gill arch bears highly vascularised double rows of primary lamellae and primary lamellae are provided with numerous secondary lamellae to enhance overall surface area. The secondary lamella has two epithelial layers with underline basement membrane supported by pillar cells. Although basic features of the gill are same, some morpho-metric features and its respiratory surface area varies among the teleosts of various habit and habitats [8].

*Corresponding author: dkmandal.vb@gmail.com 
Gill being exposed to external environment is vulnerable to pathogens and environmental contaminants. The condition of gill indicates of the health status of the fish. Modifications on the ultrastructural surface of the gill can reflect the fish health [9]. The gill is sensitive indicators of environmental stress including exposure to harmful aquatic contaminants [10]. Hence knowledge on the normal structure of the gill may be useful to know the health status of the fish. The aim of this present study is to give an account of the histology and surface ultrastructure of the gill of a minor carp, Labeo bata.

\section{Materials and Method}

\subsection{Specimen procurement and tissue collection}

The fish specimen of Labeo bata (Cypriniformes; Cyprinidae) (length 18.6 to $19.8 \mathrm{~cm}$ and weight 71.4 to $80.9 \mathrm{~g}$ ) were procured from a fish pond at Santiniketan, West Bengal, India (Lat. $23^{\circ} 14^{\prime} \mathrm{N}$ long $\left.87^{\circ} 5^{\prime} \mathrm{E}\right)$ and brought to the laboratory. Fish $(\mathrm{n}=40)$ were anaesthetized with tricaine methonesulphonate (MS 222; Sigma chemical co.) solution (100 mgL $\mathrm{mL}^{-1}$ ) and sacrificed to obtain gill tissue The gill tissues were dissected out and immediately processed for the histological and scanning electron microscopic (SEM) studies.

\subsection{Histological preparation}

The gill tissues were fixed in aqueous Bouin's fixative for a period of $20 \mathrm{hr}$ and washed repeatedly with $70 \%$ ethanol to remove picric acid. The tissues were then dehydrated through upgraded series of ethanol, cleared with benzene. The tissues were infiltrated with paraffin wax of $56-58^{\circ} \mathrm{C}$ under a thermostat vacuum paraffin embedding bath for $1 \mathrm{hr}$ and embedded in paraffin blocks. The tissue sections were cut at $4 \mu \mathrm{m}$ thickness using a rotary microtome. The tissue sections were stretched on Mayer's albuminised glass slides, deparaffinised and stained with Mayer's haematoxylin and 1\% eosin stain. Slides were examined under Olympus BX52 compound microscope and photographic image obtained.

\subsection{Histochemical preparations}

Boiun's fixed and paraffin embedded gill tissue were sectioned at $10 \mu \mathrm{m}$ thickness. The sections were then subjected to histochemical staining of periodic acid-Schiff (PAS) [11], techniques to localize acid and neutral mucin.

\subsection{Tissue preparation for scanning electron microscopy (SEM) study}

For SEM study, the gill tissues were carefully dissected out and adhering mucous was removed by repeated rinsing in $1 \%$ tween 40 solutions and fixed in $2.5 \%$ glutaraldehyde in $0.1 \mathrm{M}$ cacodylate buffer ( $\mathrm{pH} 7.2$ ) for $24 \mathrm{hr}$ at $4^{\circ} \mathrm{C}$. The tissues were washed in same buffer and post-fixed with $1 \%$ osmium tetraoxide $\left(\mathrm{OsO}_{4}\right)$ for $2 \mathrm{hr}$. Fixed tissues were washed and dehydrated in ascending grades of ethanol followed by acetone and isoamyl 
acetate. The tissues were then dried by critical point drying technique with liquid carbon dioxide in a critical point drier (Hitachi $8 \mathrm{CP} 2$ ). The completely dried olfactory tissues were mounted on metal stubs, coated with platinum (approximately $20 \mathrm{~nm}$ thick) using sputter coater (QUARUM Q150TES) and examined under a Zeiss EVO18 scanning electron microscope.

\section{Results and Discussion}

\subsection{Morphology}

Labeo bata possesses four pairs of well develop gill and each crescent shaped gill arch (average length $2.11 \pm 1.37 \mathrm{~cm}$ ) bears two rows of highly vascularised gill filaments or primary lamellae forming anterior and posterior hemibranch. Each hemibranch comprises of 131.4 \pm 29.06 number of primary lamellae (Table 1). Primary lamellae in the middle of the arch are longer than its dorsal and ventral ends being an average length of $0.75 \pm 0.13$ $\mathrm{cm}$ and breadth $0.01 \mathrm{~cm}$ (Fig. 1A). Each primary lamella is provided with two rows of many delicate rectangular flap shaped secondary lamellae in its upper and lower surfaces (Fig. 1B). Secondary lamellae are arranged at about $10 \mu \mathrm{m}$ interval throughout the primary lamellae and the number secondary lamellae in each primary lamella vary according to its length. Each gill arch supports a single row of short, soft and pointed gill rakers at the anterior concave face. The gill rakers on the ventral end are longer than that of dorsal end (Fig. 1A).

Table 1. Morphometric characters of the gill of Labeo bata.

\begin{tabular}{ll}
\hline Morphometric characters & Measurements \\
\hline Average Length of gill arch & $2.11 \pm 1.37 \mathrm{~cm}$ \\
Average Length of primary lamellae & $0.75 \pm 0.23 \mathrm{~cm}$ \\
Breadth of primary lamellae & $133.96 \pm 9.89 \mu \mathrm{m}$ \\
Length of secondary lamellae & $142.25 \pm 19.28 \mu \mathrm{m}$ \\
Height of secondary lamellae & $50.29 \pm 10.35 \mu \mathrm{m}$ \\
Breadth of secondary lamellae & $9.79 \pm 2.96 \mu \mathrm{m}$ \\
Epithelial thickness of the primary lamellae & $16.46 \pm 5.47 \mu \mathrm{m}$ \\
Primary lamellae basal membrane & $15.40 \pm 4.60 \mu \mathrm{m}$ \\
Number of primary lamellae/gill arch & $131.4 \pm 29.06$ \\
Diameter of pavement cells & $4.70 \pm 0.55 \mu \mathrm{m}$ \\
Diameter of pillar cells & $5.11 \pm 0.31 \mu \mathrm{m}$ \\
Diameter of blood cells & $4.92 \pm 0.55 \mu \mathrm{m}$ \\
Diameter of chloride cells & $11.02 \pm 1.24 \mu \mathrm{m}$ \\
Diameter of mucous cells & $12.00 \pm 0.53 \mu \mathrm{m}$ \\
\end{tabular}



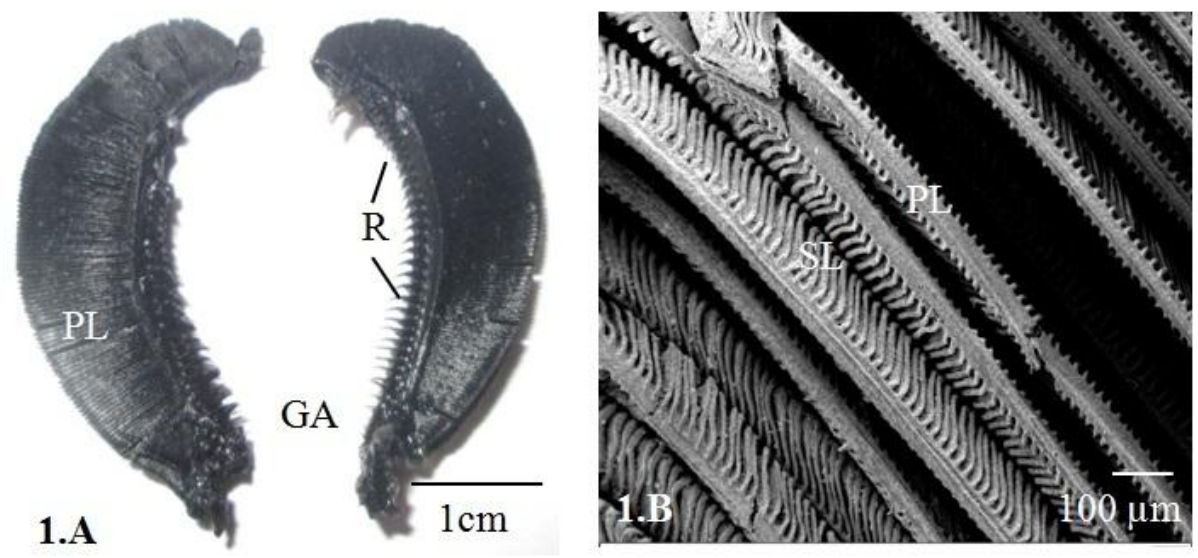

Fig. 1. Morphology of the gill of Labeo bata. 1A. Crescent shaped gill arch (GA) with two hemibranch at its convex surface. Each hemibranch consists of a series of primary gill lamellae (PL) and gill racker $(\mathrm{R})$ on its anterior concave surface. Scale bar $1 \mathrm{~cm}$. 1B. Primary lamellae (PL) are provided with series of rectangular secondary lamellae (SL) on its upper and lower surfaces.

\subsection{Histology}

Gill epithelium that covers gill arch and primary lamellae is formed of stratified epithelial cells. Epithelium of primary lamella is extended and folded in its both sides to form numerous delicate secondary lamellae of average height and breadth $50.29 \pm 10.35$ and $9.79 \pm 2.96 \mu \mathrm{m}$ respectively and these secondary lamellae are arranged perpendicularly to the primary lamellae (Fig. 2A). The free edge of the secondary lamellae is swelled up and contains blood vessel. Stratified epithelium of primary lamella is thick $(16.46 \pm 5.47 \mu \mathrm{m})$ and contains squamous epithelial cells of which surface cell layer is thin called pavement cells. Besides these cells epithelium also contains mucous cell, chloride cells and taste buds of different functions distributed randomly interspacing the epithelial cells (Fig. 2B). Mucous cells are large and oval $(12.00 \pm 0.53 \mu \mathrm{m})$ and remain concentrated at the tip of the primary lamellae and a few on the secondary lamellae. Chloride cells are large $(8.5 \pm 1.52$ $\mu \mathrm{m})$ with defused nucleus and located mainly at the basal boarder of secondary lamellae (Fig. 2C). Taste buds protruded above the epithelial surface and contain many columnar cells. The epithelium of secondary lamellae is thin and made up of single layered elliptical pavement cells measuring $5.11 \mu \mathrm{m}$ in length. The pillar cells are located in between the thin epithelium of the secondary lamellae, form the main support system and prevent collapsing the epithelium. Pillar cell consists of a large and dense nucleus that occupies most part of the cell body with irregular outline (Fig. 2C). Pillar cells are arranged in alternate with the blood channels. Pillar cells unite with neighbouring pillar cells to complete the lamellar blood channel (Fig. 2C). 

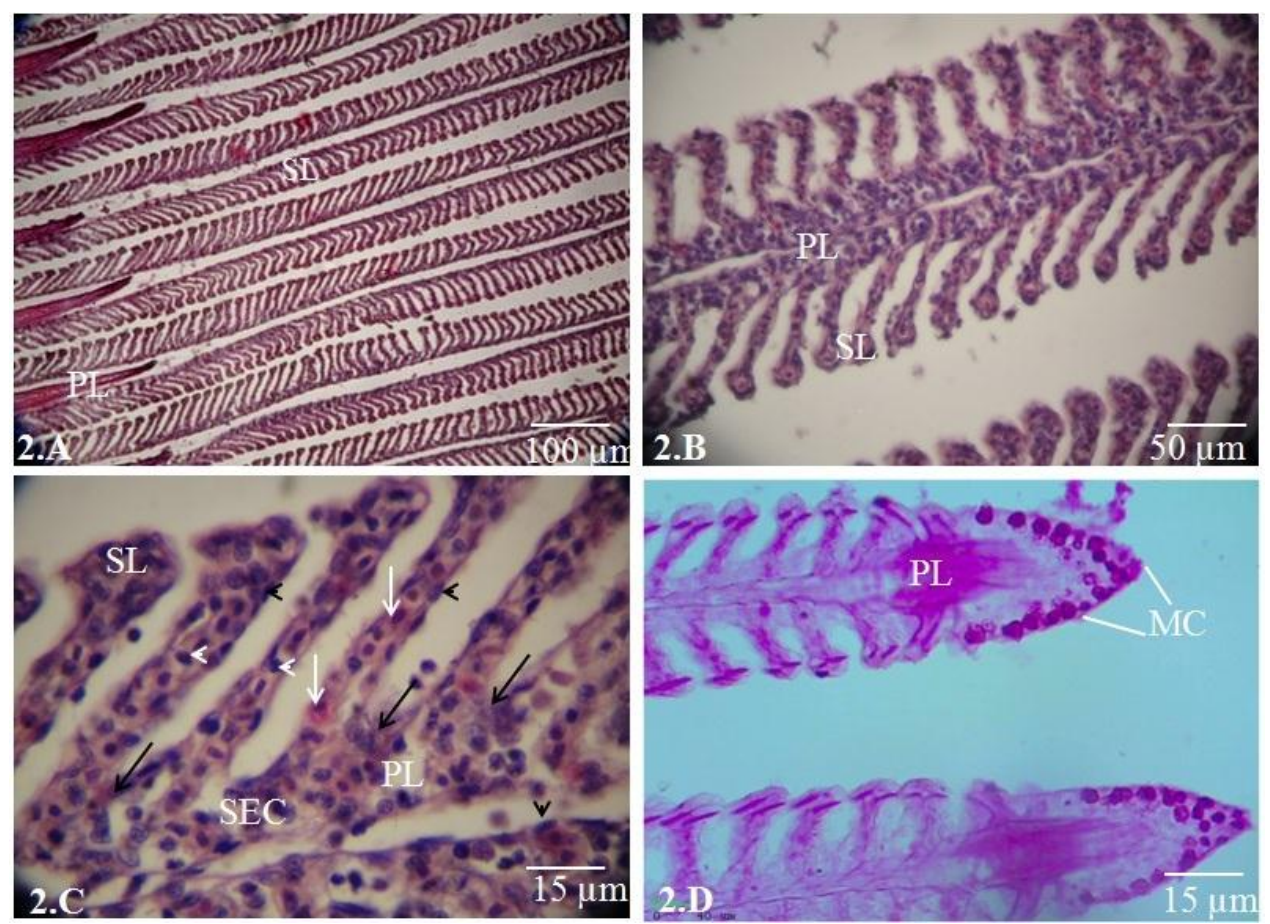

Fig. 2. Histology of the gill tissue of Labeo bata. 2A shows the secondary lamellae (SL) radiating from the both sides of primary lamellae (PL) H\&E. Bar $100 \mu \mathrm{m}$. 2B. Shows that the PL is lined with thick stratified epithelium while SL is covered with single layered epithelium H \& E. Bar $50 \mu \mathrm{m}$, 2C. Magnified view of secondary lamellae showing the Pillar cells (white arrow heads) supporting the epithelium of flat pavement cells (arrow head) and forming blood channels (white arrow). Note the presence of large chloride cells (arrow) among the stratified epithelium of PL at the junctions of SL. H \& E, Bar $15 \mu \mathrm{m}, 2 \mathrm{D}$. Demonstrate the mucous cells (MC) with PAS positive mucopolysachharide at the tip of the PL. Basement membrane shows moderate reaction, PAS, Bar $=40 \mu \mathrm{m}$.

\subsection{Histochemistry}

PAS staining localised the mucopolysaccharide substances in the mucous cells which react strongly taking magenta colour. Mucous cells are situated at the tip and the base of the primary lamellae and in the gill arch (Fig. 2D).

\subsection{Surface ultra-structure}

Rectangular shaped thin secondary lamellae are radiated from the dorsal and ventral surface of the primary lamellae (Fig. 3A). The stratified epithelium covering the primary lamellae has undulating surface appearances. The surface layer of the epithelium is made up of polygonal pavement cells with well-defined cell boundary and concentric microridges (Fig. 3B). Microridges are shallow and weakly defined. Secondary lamellae 
also covered with the same polygonal pavement cells. Stratified epithelium is interrupted by mucous cells chloride cells and taste buds. Mucous cell openings with mucin globules are present in abundance in the gill arch and primary lamellae while a few on the secondary lamellae. Crypts of the chloride cells are found in the primary lamellae particularly at the base of secondary lamellae amidst the polygonal pavement cells (Fig. 3C). The stratified epithelium covering the pharyngeal face of gill arch is characterised by depression and elevation. Cell boundary and concentric microridges marks each of the polygonal cells (Fig. 3D). Taste buds project as a conical elevation on the pharyngeal face of the gill arch. Gill rakers with pointed ends are covered with the stratified cells.
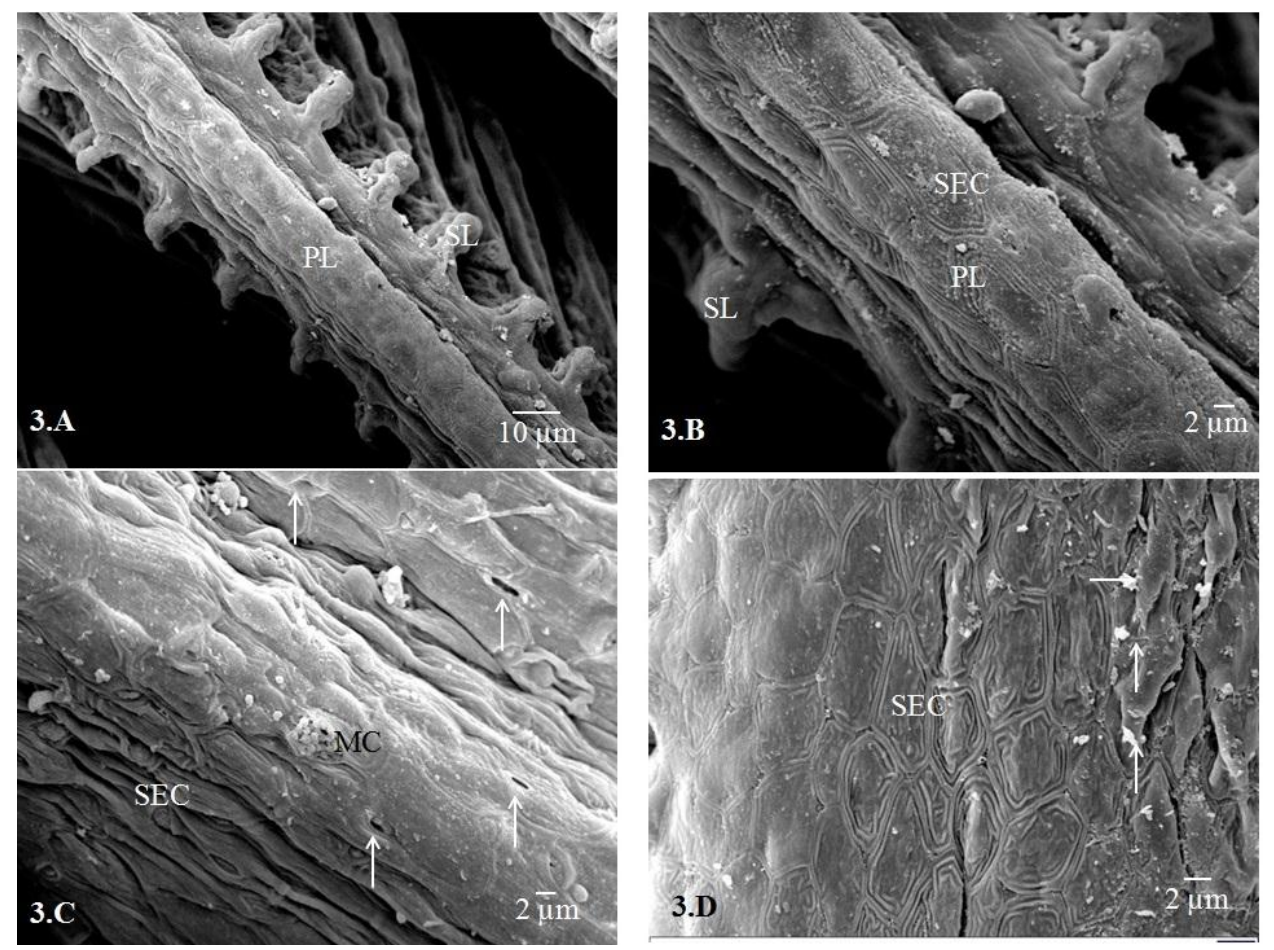

Fig. 3. Surface ultrastructure (SEM) of the gill epithelium of Labeo bata. 3A. Showing primary lamellae (PL) and radiating plates of secondary lamellae (SL). SEM. Bar=10 $\mu \mathrm{m}, 3 \mathrm{~B}$. Showing the undulating epithelium with the polygonal stratified epithelial cells (SEC) covering the PL and SL. $\mathrm{SEM}, \mathrm{Bar}=2 \mu \mathrm{m}$ 3C. Showing the gill epithelium with undulating surface, mucous cells (MC) with mucin globules and crypts of chloride cells (arrows). SEC are hexagonal and characterised by the presence of mroridges. SEM, Bar= $\mu \mathrm{m}$ 3D. The surface of PL showing SEC with well-defined cell boundary (arrows) and shallow microridges. Note the presence of mucin droplets throughout the surface, SEM, Bar $=2 \mu \mathrm{m}$.

\section{Discussion}

The morphology of the gills of Labeo bata is similar to that found in other bony fish $[7,12]$. Gill arches are curved and primary lamellae of the dorsal and ventral ends are 
shorter than that of the middle [13]. The gill raker morphology is associated with the feeding habit of the fish [14]. The short, soft and pointed gill rakers of this fish support its herbivorous feeding habit. The respiratory surface area depends of the number and length of filaments and number of secondary lamellae. The active fish has more respiratory surface area than the sluggish fish as a function of oxygen requirement [15]. The present study revealed that the number of gill filament and their average length in this fish is quite good which matches with active benthopelagic habitat of the fish. Moreover, numerous rectangular plates of secondary lamellae radiating from the both dorsal and ventral surface of the primary lamellae increased the respiratory surface area in many folds. Secondary lamellae remain spread in the aquatic media and collapse outside the water as it has no cartilage or bony support and being reduced in respiratory surface area and cause suffocation of the fish. The gill epithelium of this fish can be divided into two regions such as in the primary lamellae and gill arch it is multilayered stratified epithelium while in the secondary lamellae the epithelium is thin and made up of single layer pavement cells similar to that of other species $[16,17]$. The thickness of water blood diffusion barrier and surface area determine the diffusion rate of gases [18]. The thin single layered epithelium of the secondary lamellae thus facilitates the diffusion and exchange of gases between environment and blood. Microridges on the pavement cell surface increase the overall surface area and help in anchorage of mucous film. Pillar cells that located in the endothelium of secondary lamellae keep the thin epithelium apart from each other and form blood channels. Chloride cells are primary site of osmo-regulation in euryhaline fish. However, fish inhabiting in the freshwater possess chloride cells with wider apical surface, less evident crypts and less in abundance [19]. This observation agrees to the present study that showed a low occurrence of chloride cells. The presence of chloride cells suggests that the gill of this fish participates in osmo-regulation other than respiration. The presence of mucous cells in gill varies according to aquatic conditions [20]. Mucous cells are observed in higher number in the primary lamellae than in the secondary lamellae [21,22]. As in other fish, Labeo bata also possesses many mucous cells with PAS positive mucopolysachharide mainly at the base and tip of the primary lamellae. Mucous film may diminish gas diffusion and to avoid this interruption in gas diffusion secondary lamellae either devoid of mucous cell or possess a very few number. Mucous secretion may play different functions in the gills involving in entrapping food, lubrication and osmoregulation. Taste buds are the gustatory system that allows the fish for detection of food and swallowing and present in the oro-pharyngeal wall including on the gill arches [23]. This fish possesses less number of taste buds its gill arches.

\section{Acknowledgment}

The authors are grateful to the Head of the Department of Zoology, Visva-Bharati University, Santiniketan for providing necessary laboratory facilities and to the authority of Centre for Research in Nano-Science and Nanotechnology (CRNN), University of 
Calcutta for extending help in using Scanning Electron Microscope. Thanks are due to the University Grants Commission, New Delhi for financial assistance.

\section{References}

1. I. Samajdar and D. K. Mandal, Int. J. Pure Appl. Zool. 4(2), 134 (2016).

2. K. Roy and D. K. Mandal, Int. J. fish. aquat. stud. 2(6), 19 (2015).

3. D. H. Evans, P. M. Piermarini, and W. T. W. Potts, J. Exp. Zool. 283(7), 641 (1999). https://doi.org/10.1002/(SICI)1097-010X(19990601)283:7<641::AID-JEZ3>3.0.CO;2-W

4. A. Bhatnagar, R. Dayal, S. Chowdhary, W. S. Lakra, S. Raizada, A. K. Yadav, and P. P. Srivastava, Int. J. fish. aquat. Stud. 1(2), 45 (2013).

5. G. M. Hughes, Folia. Morphol. 18(2), 78 (1970).

6. G. M. Hughes and M. Morgan, Biol. Rev. Camb. Philos. Soc. 48, 419 (1973). https://doi.org/10.1111/j.1469-185X.1973.tb01009.x

7. J. M. Wilson and P. Laurent, J. Exp. Zool. 293, 192 (2002). https://doi.org/10.1002/jez.10124

8. H. M. Dutta and J. S. D. Munshi, Proc. Indian Acad. Sci. 94(4), 359 (1985). https://doi.org/10.1007/BF03186343

9. M. N. Fernandes and S. A. Perna-Martins, Acta. Zool. 83(4), 321 (2002). https://doi.org/10.1046/j.1463-6395.2002.00123.x

10. F. A. Vigliano, N. Aleman, M. I. Quiroga, and J. M. Nieto, Anat. Histol. Embryol. 35, 76 (2006). https://doi.org/10.1111/j.1439-0264.2005.00640.x

11. J. F. A. McManus, Nature 158, 202. (1946). https://doi.org/10.1038/158202a0

12. K. R. Olson, J. Exp. Zool. 293(3), 214 (2002). https://doi.org/10.1002/jez.10131

13. G. M. Hughes, in Fish Physiology, ed. W. S. Hoar et al. (Academic Press, Orlando, 1984) Chapter 1.

14. K. D. Friedland, D. W. Ahrenholz, J. W. Smith, M. Manning, and J. Ryan, J. Exp. Zool. 305A, 974 (2006). https://doi.org/10.1002/jez.a.348

15. G. M. Hughes and I. E. Gray, Biol. Bull. 143, 150 (1972). https://doi.org/10.2307/1540335

16. P. Laurent and S. Dunel, Am. J. Physiol. 238, 147 (1980).

17. H. C. Lin and W. T. Sung, Physiol. Biochem. Zool. 76, 215 (2003). https://doi.org/10.1016/j.aquatox.2008.02.012

18. J. Ojha and J. S. D. Munshi, Zool. Beitr. 22, 87 (1976).

19. D. R. Eiras-Stofella and S. M. Fank-de-Carvalho, Rev. Bras. Zool. 19(4), 1215 (2002). https://doi.org/10.1590/S0101-81752002000400026

20. S. E. Moron, C. A. Andrade, and M. N. Fernandes, Neotrop. Ichthyol. 7(3), 491 (2009). https://doi.org/10.1590/S1679-62252009000300017

21. F. E. Hossler, J. R Rubi, and T. D. McIlwain, J. Exp. Zool. 208, 379 (1979). https://doi.org/10.1002/jez.1402080314

22. G. M. Hughes, J. Zool. 188, 553 (1979).

23. L. Fishelson and Y. Delarea, J. Fish. Biol. 65, 651 (2004). https://doi.org/10.1111/j.0022-1112.2004.00475.x 